\title{
How Physics Makes Us Free
}

\author{
JENANN ISMAEL

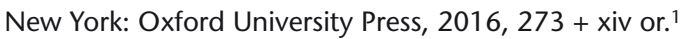

Fisikak duen munduaren ulerkera eta askatasuna (edo nork bere burua gobernatzeko gaitasuna) uztartu daitezkeela defendatu nahi du Ismaelek liburuan. Askatasuna ez dago modan, ordea. Fatalismoa da nagusi. Alde handia dago bizi dugun munduaren eta fisikak deskribatzen duenaren artean, eta ohikoa da «Bizi duguna fisikak ilusioa dela erakusten du» eta horrelakoak entzutea. Beste askori, askatasunaren defentsa metafisikoa lekuz kanpokoa irudituko zaio. Horiek, askatasuna orain eta hemen behar dela defendatuko dute. Ez duela inongo zentzurik askatasuna termino horietan pentsatzeak.

Askatasunaz hitz egiterakoan, askatasun politiko eta soziala izan ohi dugu buruan. Kasu honetan, ordea, «gogo askea» deritzon horretaz ari da egilea. Kontzientziaren mailan, gutako bakoitzak aukeratzeko, ekiteko, duen gaitasunaz; nork bere burua gobernatzeaz, alegia.

Liburu hau, gaur egungo fisikak dioena aintzat hartzen duen eta hark dioena bere munduaren ikuskeratik deslotzen ez duen edonork irakurtzekoa da. Askatasunarena bezalako galdera filosofiko handiei ezin zaizkiela erantzun berriak eman uste duten horiek ere irakurri beharko lukete liburua.

Autorearen asmoa auziaren ikuspegi orokorra eskaintzea denez, ez da auzi partikularretan sartzen, eta ez du auziak berezko duen lexiko espezializaturik ere erabiltzen. Hortaz, nahiz eta gaur egungo zientziaren filosofiaren auzi puntakoak landu, irakurle adituak eta zaletuak irakurtzeko modukoa da. Gainera, gaian sakondu nahi duenak irakurketa-gomendio osatua du liburuaren amaieran. Astun egin zaionarentzat, aldiz, liburuan zehar darabiltzan kontzeptu giltzarriak biltzen dituen glosario erabilgarria ere badu.

Baina ez du horrek bakarrik egiten liburua irakurterraz; nabarmentzekoa da Ismaelen idazkera fin eta iradokitzailea ere. Metafora zein analogia lagungarriz betea dago. Ez dago adibide beharturik, funtzio erabat didaktikoa dute darabiltzan errekurtso erretorikoek. Ez da adibideak dakarren biluztasunaren beldur, eta horrek erakusten du, hein batean, bere pentsamenduaren sendo-

1 Eskerrak eman nahi dizkiet Joana Garmendia eta Kepa Kortari, lan honen aurreko bertsioei zuzenketak eta oharrak egiteagatik. 
tasuna. Noziorik abstraktuenetik adibide lurtarrenera salto egiteko duen gaitasuna ere nabarmentzekoa da.

Liburuak bi zati ditu. Lehenengo zatiak hiru atal ditu: 70 orrialde guztira, horiek irakurri nahi ez dituen «alferrentzako eranskina» eta guzti. Bigarren zatia mardulagoa da: 130 orrialde osotara, eta bost atal. Horrez gainera, hitzatze osatua ere badu. Amaieran, lehen aipatu glosario eta irakurketa-gomendioez gain, erreferentzia-bilduma eta index lagungarria.

Liburua modu askotan irakur daiteke; mamia laugarren, bosgarren eta seigarren atalek osatzen dute eta, hortaz, gaian aditua denak zuzen jo dezake horiek irakurtzera. Hitz-atzea irakurtzea ere gomendatuko nioke. Guztia irakurri nahi ez eta aditu ez denak, aldiz, lehen kapitulua eta alferrentzako eranskina irakurri ondoren, bigarrena irakur dezake osorik. Dena den, bere prosaren iaiotasunak eta adibideen originaltasunak irakurketa atsegina eta azkarra bideratzen dutenez, liburua oso-osorik irakurtzea da aukerarik onena.

Ismaelek zera erakutsi nahi du: niaren, denboraren eta lege fisikoen inguruan ditugun zenbait gaizki-ulertu albo batera utziz gero, itxurazkoa besterik ez dela askatasunaren eta fisika klasikoaren determinismoaren arteko bateraezintasuna.

Horretarako, lehenengo atalean, gaur egungo zientziarekin bateragarria den eta erabat naturalista den niaren deskribapena egiten du; beharbada, neurozientzietan, zientzia kognitiboetan edo gogoaren filosofian dabilenarentzat ezaguna. Garenari buruz dugun ikuskera aurreteorikoa kordokan jarri gabe, bi gauza nabarmentzen ditu Ismaelek: alde batetik, nia barne-substantzia delako ikuskera kartesiarra albo batera uzten du; bestetik, defendatzen du nia ez dela guk sortzen dugun produktu bat, sortua datorkigun zerbait baizik. Norbere burua subjektu bakartzat ulertzera garamatzan prozesamendu aurrepertsonal baten sorkari gara, ez gara prozesamenduaren egile.

Lehen zatiko niari buruzko ikuspegi hori funtsezkoa izango da, ondoren, bigarren zatian Ismaelek defendatu nahi duena ulertzeko. Bigarren zatiko lehen kapituluan, liburuak erantzun nahi duen arazoa planteatzen digu Peter van Inwagenen «ondorio-argumentua» esaten zaionaren bitartez. Argumentuak honela dio:

(P1) Determinismo dinamikoari so eginez gero, iraganeko gertakari eta natura-legeak kontuan izanda, etorkizunari buruzko egia oro erator daiteke.

(P2) Iragana ez dago gure kontrolpean.

(P3) Natura-legeak ez daude gure kontrolpean.

(P4) Gure ekintzak natura-legeen eta iraganeko gertaeren ondorio dira.

Hortaz,

(P5) Gure ekintzak ez daude gure kontrolpean. 
Ismaelek (P5) faltsua dela uste du, eta, hori erakusteko, argumentuaren premisen baitan gordean dagoen kausalitatea, natura-legeen eta denboraren ulerkera aldatzea izango da bere estrategia. Newtondar mekanikaren legeak ez direla deterministak bakarrik, lege lokalak ere badirela dio. Alegia, baldintza isolatu zein idealizatuetan gauzen portaera zein den azaltzen duten legeak. Hori dela eta, maila mikroan determinismoak duen eraginak muga oso malguak edo ahulak ezartzen dizkio maila makroko fisikari. Hortaz, gu bezalako sistema batek, alegia, nork bere burua gobernatzeko gaitasuna duenak, agentea bere ingurunearen mugetatik deslotzeko gaitasuna du, hein batean, erabakimenari «funtsezko kontrola» emanez. Sistema batek bere portaeraren funtsezko kontrola duela diogu, sistemaren barneko edo baitako prozesuek rol erabakitzailea badute sistema beraren portaeraren sorkuntzan. Ismaelek ez dio esperientzia fenomenikoa edo «qualia» esan izan zaiona zergatik dugun galderari erantzuten. Liburuaren helburua beste bat da. Nolabait esanda, gure erabakimenak funtsezko kontrola duela behin onartuta, eta niaren ikuspegi naturalizatu batetik abiatuta, hori bermatzen duen eustazpian jartzen du arreta. Esan bezala, argumentuaren premisen baitan gordean dagoen kausalitatea, natura-legeen eta denboraren ulerkera aldatzea izango da bere estrategia.

(P1)en arabera, etorkizuneko gertakariak ezagut genitzake iraganeko gertakariak eta horiek gobernatzen dituzten natura-legeak aintzat hartuta. Ismaelek dio, (P1)en noranzko bat dagoela gordean, iraganak etorkizuna kausatzen duelako ideia. Hori dela eta, kausalitatea ulertu beharra azpimarratzen du. Russellekin bat eginez, defendatzen du kausalitaterik ez dagoela lege orokorren mailan; alegia, natura-legeek gauzak nolako portaera duten azaltzen digutela, baina ez dutela argitzen, ez gertaera batek beste batekiko duen beharrezkotasun kausala, ez noranzkoa. Natura-legeak simetrikoak dira. Kausalitatea, aldiz, erlazio asimetrikoa da: erreferentziamarkoaren, zirkunstantzien eta agentearen asmoen araberakoa. Alabaina, nahiz eta kausalitateak ez duen rolik natura-lege oinarrizkoen mailan, funtsezkoa da natura-lege oinarrizkoen baitatik sortzen diren erregulartasun emergenteak baliatuz ekiten duten gu bezalako agenteentzat. Hori da, hain zuzen ere, gaur egun zientziak kausalitatea ulertzeko duen era: agenteak dituen helburu praktikoak gauzatzeko helbide estrategikoa da. Kausalitatea, hortaz, Ismaelen arabera, askatasunaren adierazle litzateke, eta ez alderantziz. Iraganeko gertakariak eta horiek gobernatzen dituzten naturalegeak etorkizuneko gertakariak eratortzeko erabil litezkeen moduan, etorkizuneko gertakariak eta horiek gobernatzen dituzten natura-legeak erabil litezke iraganeko gertakariak eratortzeko. Behin (P1)en gordean dagoen kausalitatearen ulerkera zuzenduta, iraganetik etorkizunerako «konpultsio» hori albo batera utzi beharko genuke.

(P3) Kausalitatearekin gertatzen den moduan, bi lege mota ezberdinen araberako fisika-legeak ulertzeko bi era ezberdintzen ditu Ismaelek. Alde 
batetik, lege lokalak, edo baldintza isolatu zein idealizatuetan gauzen portaera zein den azaltzen duten legeak, egongo lirateke. Lege horietatik eratortzen den legeen ulerkera ere «lokala» edo «kokatua» litzateke; zientzialariek normalean izan ohi dutena, alegia. Bestalde, lege globalak egongo lirateke: unibertsoa bere osotasunean deskribatu asmo luketen lege lokaletatik eratorritako lege emergenteak. Lege horietatik sortzen den ikuskera, aldiz, globalista ${ }^{2}$ litzateke, filosofo eta kosmologoen artean hedatuen dagoen ikuspegia:

Lehenengo deskribapenak [ulerkera lokalak], bi sistema irekiren (ikertzailea eta ikergai den sistema) arteko jardun engaiatu bezala ikusarazten digu ikerketa zientifikoa. Lege globaletan azpimarra egiteak, aldiz, gu geu parte garen, unibertso amaitu baten ikuskera desgorpuztura garamatza. Gainera, arestiko deskribapenak [ulerkera lokalak] unibertsoko zatien portaera deskribatzen duten legeak oinarrizkotzat eta lege globalak horiengandik eratorriak ikusarazten dizkigu. Lege globaletan azpimarra egiteak, aldiz, lege globalak oinarrizkotzat eta edozein azpisistema irekiren portaeraren deskribapena osotasun baten osatugabeko deskribapentzat hartzera garamatza. (110 or. $)^{3}$

Ikuskera globalista hartzeak legeak reifikatzea dakar; eta, gertaerek legeak mugatu beharrean, legeek gertaerak mugatzen dituztela pentsatzera eraman gaitzake. Ismaelentzat, hori da, hain zuzen, «ondorio-argumentua» baleko egiten duena. Behin ikuspegi globalista hori albo batera utzita, (P3)ren indarra ez da horren agerikoa. Legeek gertaerak mugatzen ez badituzte, eta guk gertaeretan esku hartzeko gaitasuna badugu, Ismaelen arabera, fisika-legeak, modu oso partzialean bada ere, guk eraginak dira, eta, hortaz, gure «kontrolpean» daude. Dena den, ez dirudi (P3)ren aurkakoa ere onartuko lukeenik; «kontrol» hitzarekin zer esan nahi duen ez dago argi, ez dirudi normalean erabiltzen dugun esanahia duenik buruan. Badirudi, hemen ere, ezinbestekoa dela maila mikroko eta makroko fisika kontuan izatea «kontrol» hitzaren zentzua ulertzeko.

Amaitzeko, eta honekin lotuta, seigarren atalean, (P2)k dioena, alegia, iragana ez dagoela gure kontrolpean, zer zentzutan ulertu behar den

\footnotetext{
2 Ikuskera globalista honen kalteak filosofiako beste eremuetan ere nabarmentzen dira. Gogoaren eta hizkuntzaren filosofian ikuspegi globalista honen kalteei buruz, irakurri Perry (2003).

3 «The earlier description made us think of scientific investigation as an active investigation between one open system (an experimenter) and another (the system under study). The focus on the global laws, by contrast, encourages a disembodied view of a closed universe, of which we ourselves are parts. And the earlier description made us think of the laws that describe the behavior of components of the universe as basic and the global laws as derivative. The focus on global laws, by contrast, makes us think of the global laws as basic, and any description of the behavior of open subsystems as an incomplete description of the whole». (110 or.)
} 
aztertzen du. Lege fisikoek, lehen esan bezala, ez diote iragana, orainarekiko zein etorkizunarekiko, ontologikoki ezberdina edo pribilegiatua denik. Ordea, gure esperientziak kontrakoa erakusten digu: uste dugu ezin dezakegula etorkizuna ezagutu iragana ezagutzen dugun modu berean (asimetria epistemikoa); eta, ezin dezakegula eragin iraganean, etorkizunean eragin dezakegun eran (asimetria praktikoa). Ismaelek argudiatzen $\mathrm{du}$ asimetria horien jatorria esku hartzen duen agentearen perspektibaren ondorio dela. Behatzaile hutsak izango bagina, denbora ez litzateke hiru dimentsioen antzerako beste dimentsio bat besterik. Ordea, esku har dezakegula ikusteak, eta gure ekintzak aukeramen horren ondorio direla ikusteak, espazioa eta denbora ezberdintzera garamatza. Denbora ez da ziurgabetasuna argitzen den dimentsioa bakarrik, espazioaren kasuan gertatzen den bezala; izan zitekeena eta dena argitzen den dimentsioa ere bada. Horregatik, iraganaren eta etorkizunaren arteko aldea ez da epistemikoki soilik ulertu behar, praktikoa ere bada; gure ekiteko gaitasunaren ondorio zuzena da. Hortaz, (P2) zentzu honetan ulertuta, askatasunaren ondorio izango litzateke.

Zazpigarren eta zortzigarren ataletan, aurreko hiru kapituluetan garatutako ideiak aplikatzen ditu Michael Scrivensen «Aurresateko gaitasunaren paradoxa» eta fatalismoaren auziari modu dotorean erantzuteko. Azken atala — beharbada liburuko ahulena—, aldiz, autoeraketari buruzkoa da. Funtsean, erabakiak hartuz egiten dugula, partzialki bada ere, gure bizitza den bezalakoa, diosku. Darraion hitz-atzeak interes handiagoa du, liburuan defendatutakoaren laburpen osatua egiten baitu.

Zalantza bat: badirudi fisika kuantikoak erakusten duela naturan indeterminismoa dela nagusi, eta ez determinismoa. Horren argitan, batek galde dezake ez ote den anakronikoa Ismaelen defentsa. Autorearen erantzuna garbia da: fisika kuantikoa oraindik ez dugu guztiz ulertzen horrelako auzi batean izan ditzakeen ondorioak ateratzeko; gainera, askatasuna auzitan jarri duena, historikoki, determinismoa dela ulertu izan da, eta horren adierazlerik argiena mekanika klasikoa da; amaitzeko, newtondar legeak dira, gaur-gaurkoz, agentearen mailako fisika eraginkorra. Hortaz, erabateko zentzua dauka zer askatasun mota den posible ezagunak diren fisika klasikoaren mugen baitan galdetzeak. Jakinik, fisika determinista ote den galdera erantzun gabe dagoela.

Oso baliagarria da liburua: denbora, legeak, kausalitatea, objektu/subjektu bereizketa, lehenengo/hirugarren pertsona bereizketa, transzendente/ kokatu bereizketa birpentsatzeko bide ematen baitu, besteren artean; guztiak ere filosofian dagitenentzat garrantzitsuak diren zehar-kontzeptuak. Datorrenaren zain dagoen gizartearen garaian, galdera filosofiko handiek erantzun berririk ezin jaso dutela diotenen kontra, askatasunaz pentsatzea merezi duela erakusten du Ismaelen liburuak. 


\section{Erreferentziak}

PERRY, John. 2003. «The subject matter fallacy». Journal of Applied Logic 1 (1-2): 93-105. https://doi.org/10.1016/S1570-8683(03)00005-3

Beñat Esnaola $\mathrm{UPV} / \mathrm{EHU}$ 